\title{
What Do We Know About Tariff Incidence?
}

Stephen Tokarick 


\title{
IMF Working Paper
}

Research Department

\section{What Do We Know About Tariff Incidence?}

\author{
Prepared by Stephen Tokarick ${ }^{1}$ \\ Authorized for distribution by Shang-Jin Wei
}

September 2004

\begin{abstract}
This Working Paper should not be reported as representing the views of the IMF. The views expressed in this Working Paper are those of the author(s) and do not necessarily represent those of the IMF or IMF policy. Working Papers describe research in progress by the author(s) and are published to elicit comments and to further debate.
\end{abstract}

This paper examines the question: Who bears the larger portion of the excess burden of a tariff-the country that imposes it, or a country that it trades with? For a country that can influence its terms of trade, there are two ways of approaching this question. This paper shows that under certain assumptions, the extra burden from a marginal change in the homecountry tariff is shared equally between the home and foreign country at a tariff rate equal to twice the optimal tariff for the home country. Also, the cumulative welfare effect of a tariff in the home country, relative to free trade, turns out to be equalized across countries when the home tariff equals four times its optimal tariff. The paper provides an application of these results and points policymakers to the types of data that are relevant if they want to negotiate over "burden sharing."

JEL Classification Numbers: F13, H22

Keywords: tariffs, excess burden, tax incidence offer curves

Author(s) E-Mail Address: stokarick@imf.org

\footnotetext{
${ }^{1}$ The author would like to thank Mary Amiti, Jim Cassing, Alan Deardorff, Richard Harris, Michael Keen, Arvind Panagariya, Azim Sadikov, Maurice Schiff, and Yongzheng Yang for useful discussions.
} 


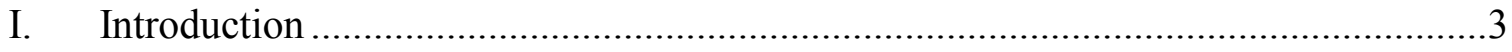

II. Tariff Incidence in General Equilibrium ..............................................................5

A. Welfare Effects from a Marginal Change in the Home Tariff............................6

B. Distribution of the Cumulative Welfare Effects of a Tariff ..............................13

C. Generalizations and Extensions ............................................................. 16

III. Numerical Applications ............................................................................... 16

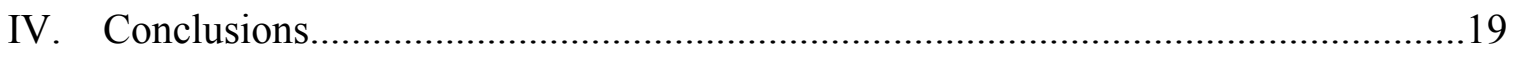

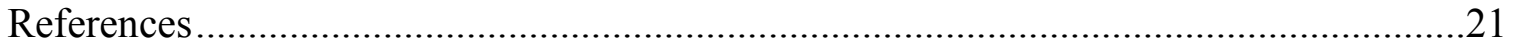

Table 1. Incidence of Quad Country Tariffs: Three Examples from Agriculture ............18

Figures

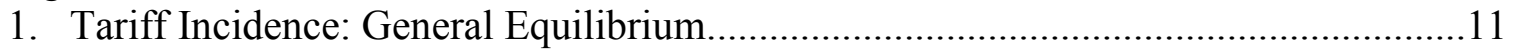

2. Distribution of Welfare Effects from a Tariff in the Home Country .........................12 


\section{INTRODUCTION}

Recently, there has been quite a lot of theoretical and practical interest in the question of how protection in advanced economies affects developing countries. Some argue that industrial country protection is more harmful to developing countries than is developing coutnries' own protection, and cite the high levels of support provided to agricultural sectors in industrial countries as an example. On the other hand, others argue that the pattern of protection in developing countries retards their development more than industrial country trade barriers, so developing countries would benefit more from reducing their own barriers. Thus, the question boils down to who bears the larger portion of the deadweight loss from protectionthe country that puts the protection in place or a country's trading partner?

One view is that industrial country protection hurts developing countries more than their own protection. An example of support for this position is found in Stoeckel and Borrell (2001) who state:

High income countries lose from agricultural protection by paying more than they need to for agricultural products. But low income countries are also big losers. Agriculture is much more important to low income countries than to high income countries-chart 3. The distortions of world trade by high income countries therefore hurts low income countries the most. ${ }^{2}$

In discussing the effects of the European Union's sugar policy, Oxfam (2002) states:

EU consumers and taxpayers pay a high price for the excessive production, but the real burden falls far beyond Europe's borders. Not only is Europe depressing the world price and keeping out efficient suppliers like Brazil and Thailand, but it is also destroying prospects for some of the least developed countries (LDCs), such as Mozambique. ${ }^{3}$

In advocating an alternative view, Bhagwati (2002) acknowledges that protection in rich countries matters, but argues that developing countries could help themselves by reducing

${ }^{2}$ Andrew Stoeckel and Brent Borrell (2001), "Preferential Trade and Developing Countries: Bad Aid, Bad Trade," Rural Industries Research and Development Corporation, page 11. Later in the paper, the authors seem to take the opposite view. For example, on page 19, the authors state: "Countries stand to gain far more from reducing their own barriers to trade than by waiting for some other country in the world to remove barriers to their exports."

3 “The Great EU Sugar Scam: How Europe's Sugar Regime is Devastating Livelihoods in the Developing World," (2002), Oxfam Briefing Paper 27, page 4. 
their own barriers to trade, which are substantial. Using the Lerner symmetry theorem (1936), Bhagwati argues that it is not protection in rich countries, but rather the high levels of protection in developing countries that have kept their exports from growing more rapidly. In addition, he points out that tariffs in developing countries are, on average, higher than in rich countries. He argues further that "Moreover, the trade barriers of the poor countries against one another are more significant restraints on their own development than those imposed by the rich countries."

While Bhagwati is certainly factually correct in pointing out that developing country tariffs are higher than those in rich countries, it is another question what the magnitude of the resulting welfare effects are. As is well known, the welfare effects of a tariff depend on the elasticity of demand for imports and the share of imports in GDP, not just the height of the tariff. And, there is the issue of whether developing countries are able to influence their terms of trade by imposing tariffs or export taxes. Thus, while Bhagwati may be correct that developing country barriers are more costly, in the end, the size of the welfare effects is an empirical matter. It is not necessarily the case that the country that imposes the higher trade barrier suffers a larger welfare loss.

The purpose of this paper is to examine, from the point of view of trade theory, what is currently known about the incidence of the burden generated by protection. Several papers have examined the distribution of the welfare effects of a "tariff war," including Gorman (1958), Johnson (1953-54), and Kennan and Riezman (1988), where, in a two-country setting, each country reacts to the other's trade policy. Alternatively, Markusen (1981) examined the distribution of the gains from bilateral tariff reductions in a two-country model. Unlike these previous papers, this paper only considers the effects of changes in the level of protection by one country, holding the other country's trade policy constant.

The main result of this paper is that in the case where a country is able to influence its terms of trade, there is no theoretical basis for the position that most of the excess burden of a tariff must be borne by the country that imposes it - it is an empirical matter. The fact that many studies of the costs of protection (e.g., Anderson and others, 2001, and Tokarick, 2003) find that the country that imposes the protection bears most of the cost is an empirical finding, not a theoretical one. Also, simply comparing the height of tariffs across countries does not necessarily reveal any information about who bears the largest portion of the deadweight loss, as this depends on elasticities and trade shares, as well as the size of the distortion. ${ }^{5}$

This paper addresses the question of who bears the burden of protection from two perspectives. First, the paper derives the welfare effect of a marginal change in a country's tariff on the country itself and its trading partner. Second, the paper analyzes the cumulative welfare effect of a tariff relative to free trade, across both the home and foreign country.

\footnotetext{
4 “The Poor's Best Hope," The Economist, June, 2002, pp. 24-26.

${ }^{5}$ A similar point was emphasized by Markusen (1981), who found that no judgement can be made about the welfare effects of bilateral tariff reductions by examining tariff rates alone.
} 
Markusen (1981) only examines the case of a marginal change in bilateral tariffs on country welfare. For each of these cases, this paper derives conditions that determine how the welfare of each country is affected by protection in one country. The paper also suggests a simple way to apply the theoretical results to questions about tariff incidence across countries.

\section{TARIFF INCIDENCE IN GENERAL EQUILIBRIUM}

It is well known that the excess burden of a tariff imposed by a small country falls entirely on that country. Since it cannot affect its terms of trade, a small country cannot shift any of the excess burden of a tariff onto another country. In the case of a tariff imposed by a large country, the distribution of the welfare effects across countries depends on the elasticity of the foreign offer curve and where the home tariff rate lies in relation to its optimal tariff.

Suppose that there are two countries, home and foreign, and each starts from a situation of free trade. Assume that the home country produces two goods, an importable and an exportable, and it is able to influence its terms of trade. Further, assume that the foreign country does not retaliate against the home country, so the effect of a tariff by the home country on the welfare of the foreign country is a negative terms-of-trade change. ${ }^{6}$ The imposition of a tariff by the home country will raise its own welfare up to the point where the optimal tariff $\left(t^{*}\right)$ is reached. ${ }^{7}$ Therefore, for tariffs in the range of zero to $t^{*}$, the home country gains from an increase in its tariff. With no other distortions, a tariff must lower world welfare. So, in a two-country model, it must be the case that the foreign country loses from a tariff by the home country in the range between zero and $t^{*}$, and it loses by more than the loss in world welfare, as the home country gains.

Tariff increases by the home country above $t^{*}$ up to the prohibitive tariff rate- the rate that would shut off trade - would reduce home welfare. Tariff increases in this range would still improve the home country's terms of trade, but the additional distortionary cost would outweigh this beneficial effect. And, since it could still improve its terms of trade, the home country could shift at least part of the excess burden of a tariff onto a trading partner. So the question of who bears the burden of a tariff is only interesting for tariff levels between the optimal tariff and the prohibitive tariff for the home country.

In a general equilibrium setting, the welfare effect of an import tariff on the country that imposes it is, following Caves, Frankel, and Jones (2002) given by:

$$
d y=-M d p^{*}+\left(p-p^{*}\right) d M
$$

\footnotetext{
${ }^{6}$ This assumption is realistic in the sense that a significant period of time may pass before a country responds to the protectionist devices of the imposing country, especially if the aggrieved country pursues a trade remedy through the World Trade Organization (WTO).

${ }^{7}$ As is well known, the optimal tariff is $t^{*}=1 /\left(\varepsilon^{*}-1\right)$, where $\varepsilon^{*}$ is the elasticity of the foreign offer curve.
} 
where $d y$ is the change in real income in the home country, $M$ is the quantity of imports, $d M$ is the change in imports, $p$ is the relative price of imports in the home country (price of exports is numeraire), $p^{*}$ is the world price, and $d p^{*}$ is the change in the world price of the protected commodity. As the foreign country has no distortions of its own in place, the welfare effect of a tariff imposed by the home country on the foreign country is:

$d y^{*}=E^{*} d p^{*}$

where $d y^{*}$ is the change in real income in the foreign country and $E^{*}$ denotes exports from the foreign country.

Rewriting equation (1) following Caves, Frankel and Jones (2002) gives:

$d y=-p^{*} M \hat{p}^{*}+\left(t p^{*} M\right) \hat{M}$

and using the solutions for $\hat{p}^{*}$ and $\hat{M}$ from a tariff:

$$
\begin{aligned}
& \hat{p^{*}}=\frac{1}{\left(\varepsilon+\varepsilon^{*}-1\right)} \beta d t \\
& \hat{M}=-\varepsilon \hat{p}^{*}+\beta d t
\end{aligned}
$$

where $\beta=-(\bar{\eta}+e)<0, \bar{\eta}$ is the elasticity of substitution in demand between goods, $e$ is the elasticity of supply of exports, $\varepsilon$ is the elasticity of import demand along the home offer curve, $\varepsilon^{*}$ is the elasticity of import demand along the foreign offer curve, and $d t$ is the change in the home country tariff. The term $\left(\varepsilon+\varepsilon^{*}-1\right)$ is assumed to be positive throughout this paper, as it is the Marshall-Lerner stability condition.

\section{A. Welfare Effects from a Marginal Change in the Home Tariff}

Suppose that the home country alters its tariff. Then the welfare effect from this marginal tariff change will be equalized across both countries at the tariff rate in the home country where $\frac{d y}{d t}$ equals $\frac{d y^{*}}{d t}$. Substituting (4) and (5) into (3) gives:

$$
\frac{d y}{d t}=\frac{-p^{*} M \beta}{\left(\varepsilon+\varepsilon^{*}-1\right)}-\frac{\varepsilon \beta\left(t p^{*} M\right)}{\left(\varepsilon+\varepsilon^{*}-1\right)}+\beta\left(t p^{*} M\right) .
$$

Following a similar procedure for deriving the effect of a change in the home-country tariff on welfare in the foreign country, using (2) and (4) gives: 
$\frac{d y^{*}}{d t}=\left(p^{*} E^{*}\right)\left(\frac{1}{\varepsilon+\varepsilon^{*}-1}\right) \beta<0, \forall t$

since $\beta$ is negative. Solving for the home-country tariff rate that equates (6) and (7) gives:

$$
\bar{t}=\frac{\left(\frac{p^{*} E^{*}}{p^{*} M}\right)+1}{\left(\varepsilon^{*}-1\right)}
$$

Note that when trade is balanced (as would be the case in a two-country world), then the tariff rate in the home country where the change in real income is equal in both the home and foreign countries satisfies:

$\bar{t}\left(\varepsilon^{*}-1\right)=2$, or $\bar{t}=\frac{2}{\left(\varepsilon^{*}-1\right)}$.

At $\bar{t}$, both $\frac{d y}{d t}$ and $\frac{d y^{*}}{d t}$ are negative and intersect. Substituting (9) into (6) gives:

$\left.\frac{d y}{d t}\right|_{t=\bar{t}}=\frac{p^{*} M \beta}{\left(\varepsilon+\varepsilon^{*}-1\right)}<0$, since $\beta<0$

and using (7), $\frac{d y^{*}}{d t}$ is negative for all tariff rates. The fact that $\frac{d y}{d t}$ is negative at $\overline{\mathrm{t}}$ guarantees that $\overline{\mathrm{t}}$ is greater than $t^{*}$ (the optimal tariff) because by definition, $\frac{d y}{d t}$ equals zero at $t^{*}$. Both $\frac{d y}{d t}$ and $\frac{d y^{*}}{d t}$ intersect at $\overline{\mathrm{t}}$ because: 
$\left.\frac{d^{2} y}{d t^{2}}\right|_{t=\bar{t}}=\frac{p^{*} M \beta\left(\varepsilon^{*}-1\right)}{\left(\varepsilon+\varepsilon^{*}-1\right)}<0$, provided $\left(\varepsilon^{*}-1\right)>0^{8}$, since $\beta<0$

and using (7)

$\left.\frac{d^{2} y^{*}}{d t^{2}}\right|_{t=\bar{t}}=0$

From (11) and (12), the slope of $\frac{d y}{d t}$ is steeper (more negative) than $\frac{d y^{*}}{d t}$ at tariff rate $\bar{t}$, therefore, $\frac{d y}{d t}$ must intersect $\frac{d y^{*}}{d t}$.

Equation (9) defines the tariff rate in the home country where the excess burden from a marginal tariff change is shared equally across the home and foreign country. An increase in the home tariff above $\bar{t}$ would result in the home country bearing more of the excess burden. Conversely, if the current tariff rate in the home country were below $\bar{t}$, a tariff increase would hurt the foreign country by more than it would hurt the home country.

In the case where the elasticity of the foreign offer curve $\varepsilon^{*}$ remains constant as the home offer curve shifts, then $\bar{t}=2 t^{*}$, using equation (9), where $t^{*}$ is the optimal tariff. Constant elasticity functions were used by both Johnson (1953-54) and Gorman (1958) to analyze whether a country could make itself better off by imposing an optimal tariff in the presence of foreign retaliation. ${ }^{9}$

The result discussed above follows from the fact that for a marginal tariff change in the home country to produce the same change in real income in both the home and foreign countries, the extra distortionary cost from a tariff increase in the home country must be twice as large as the terms-of-trade effect. This is because in the home country, the welfare effect of a tariff increase is comprised of two parts: a terms-of-trade gain and a distortionary cost, while in the foreign country, the welfare effect is just a terms-of-trade loss. Under certain assumptions about demand behavior, the terms-of-trade gain in the home country is exactly offset by the

\footnotetext{
${ }^{8}$ The condition $\left(\varepsilon^{*}-1\right)>0$ is assumed to hold, because the home country would always change its tariff so as to operate on the elastic section of the foreign offer curve.

${ }^{9}$ Hamilton and Whalley (1983) explore the implications of this assumption.
} 
terms-of-trade loss in the foreign country, as trade is balanced. ${ }^{10}$ The change in welfare from a tariff imposed by the home country is (TOT - DC), while in the foreign country the welfare effect is (-TOT), where TOT is the terms-of-trade effect of a tariff and DC represents the extra distortionary cost. At the tariff rate in the home country where the change in real income in both countries is equal,

$-T O T=T O T-D C$

or,

$D C=2 T O T$

At the optimal tariff for the home country, the extra distortionary cost from a small tariff increase equals the terms-of-trade gain (the change in welfare is zero). Increases in the tariff rate by the home country above the optimal tariff will lower home welfare, as the extra distortionary cost exceeds the terms-of-trade gain. In fact, the distortionary cost grows twice as fast as the tariff rate. The distortionary cost component can be written as ${ }^{11}$ :

$D C=-\varepsilon_{d} p^{*} M t^{2}$

so

$\frac{d D C}{d t}=-2 t \varepsilon_{d} p^{*} M$

where $\varepsilon_{\mathrm{d}}$ is the price elasticity of demand for imports. The terms-of-trade effect of a tariff imposed by the home country is:

$T O T=-M d p^{*}=-p^{*} M \hat{p^{*}}=-\frac{p^{*} M \beta}{\left(\varepsilon+\varepsilon^{*}-1\right)} d t$

so:

${ }^{10}$ If the marginal utility of income is the same in both countries, then the terms-of-trade effects cancel out across countries.

${ }^{11}$ See Panagariya (2002) for a survey. 


$$
\frac{d T O T}{d t}=-\frac{p^{*} M \beta}{\left(\varepsilon+\varepsilon^{*}-1\right)}
$$

which depends on the tariff rate in the home country, but not the square of the tariff. Using these results, if the home country started from its optimal tariff, $t^{*}$, then an increase in its tariff to $2 t^{*}$ would approximately quadruple the distortionary cost component (using 15), while the terms-of-trade benefit would only about double. Therefore, at the new tariff rate $2 t^{*}$, the extra distortionary cost would be twice the terms-of-trade gain.

Figure 1 summarizes the results derived above. The upper panel of figure 1 plots the level of real income in the home country as a function of the tariff rate. At a zero tariff at home and abroad, the home country enjoys a level of real income associated with free trade. Increases in the tariff rate in the home country up to $t^{*}$ raise real income. At tariff rate $t^{*}, \frac{d y}{d t}=0$, since $t^{*}$ is the optimal tariff rate, and tariff rates greater than $t^{*}$ reduce home welfare. Once the prohibitive tariff, $\mathrm{t}^{\mathrm{p}}$ is reached, welfare in the home country falls below the free-trade level and further increases in the tariff rate have no affect. Since home-country welfare rises with tariff rates between zero and $t^{*}$, and then falls, $\frac{d y}{d t}$ plotted in the lower section of figure 1 , lies above the horizontal axis for tariffs less than $t^{*}$ and below the horizontal for tariffs greater than $t^{*}$. For the foreign country, its welfare declines with the home country tariff, as shown in (7), and $\frac{d y^{*}}{d t}$ is horizontal due to (12).

Figure 2 illustrates the possible outcomes for both the home and foreign countries as a result of changes in the home country tariff. In general, the distribution of the welfare effects of protection in the home country depends on where the equilibrium lies relative to the freetrade equilibrium and how the home country offer curve shifts from a tariff change. Suppose the initial (free-trade) equilibrium occurred at point F. Then, the home country could improve its welfare by imposing an optimal tariff - shifting the home offer curve so that it intersected the foreign offer curve at $\mathrm{P}$. A further increase in the home-country tariff could result in an equilibrium at $\mathrm{B}$ and suppose that the movement from $\mathrm{P}$ to $\mathrm{B}$ produces an equal change in real income in both countries. If the free-trade equilibrium occurred on the segment of the foreign offer curve OB, then the home country could not change its tariff in a way that would produce an equal change in real income in both countries. Along segment $\mathrm{OB}$, the foreign offer curve is highly elastic, and its elasticity increases in the direction of the origin. Therefore, the home country has little scope for altering the terms of trade. This situation is close to the small country case.

Alternatively, a tariff change by the home country could result in a movement to autarky. In equation (5), the term $(\beta \mathrm{dt})$ measures the shift in the home-country offer curve from a tariff, and $\beta=-(\bar{\eta}+e)<0$. If $\beta$ is large in absolute value, then a tariff increase by the home country could move both countries to autarky. The change in the home-country tariff needed to reach autarky, starting from free trade, is 
Figure 1. Tariff Incidence: General Equilibrium

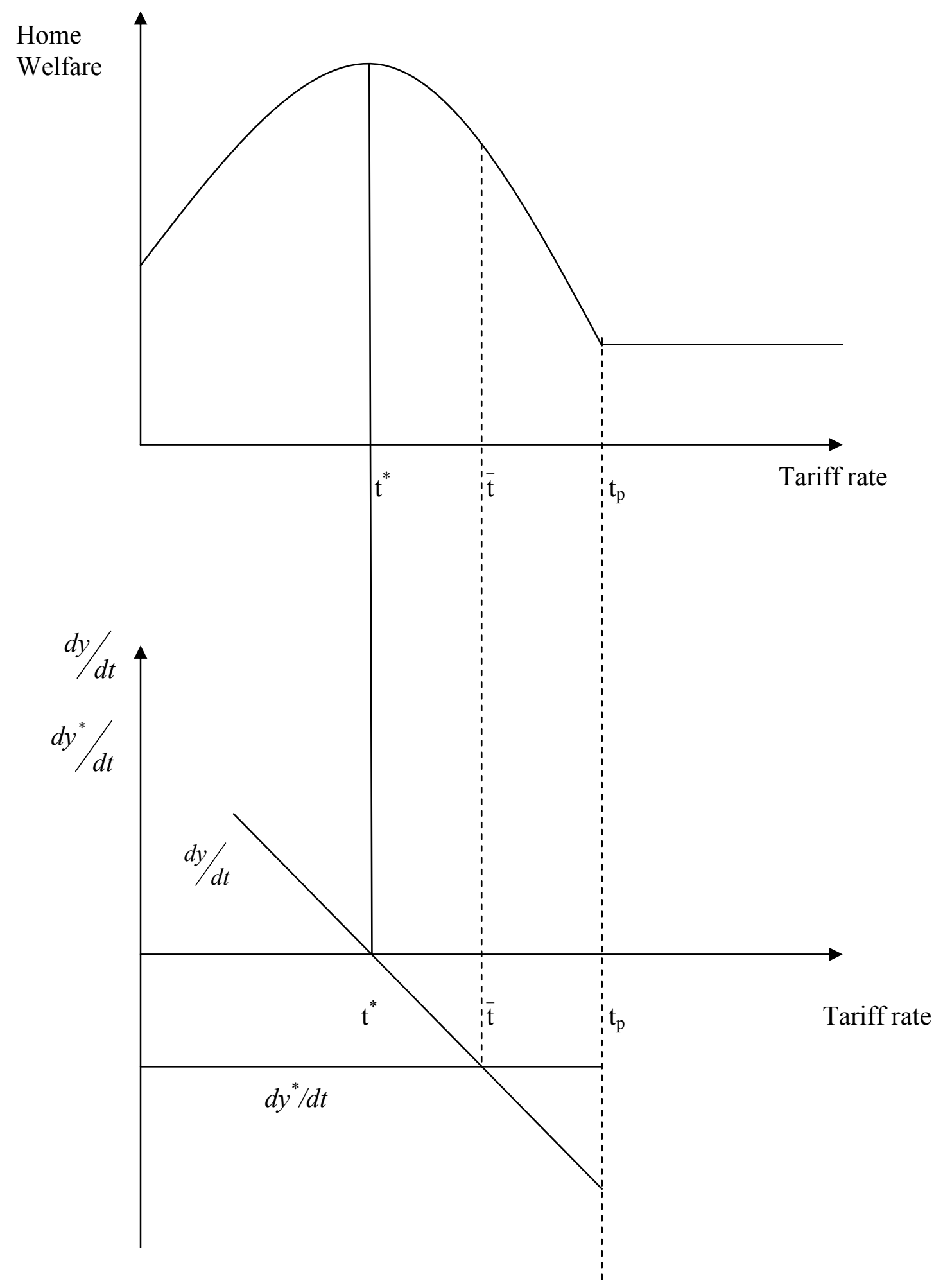


Figure 2. Distribution of Welfare Effects from a Tariff in the Home Country

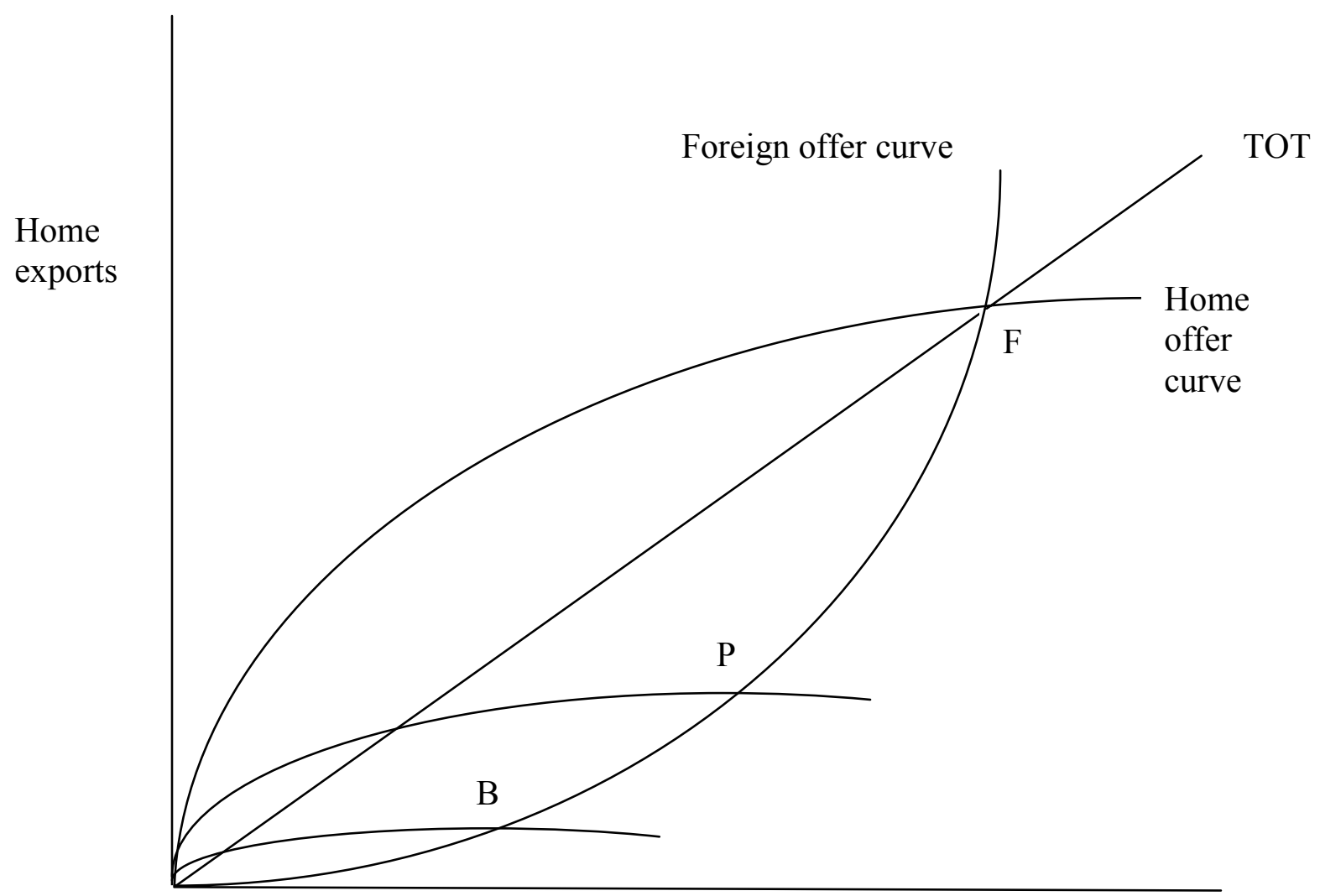

$\mathrm{O}$

Home imports

$d t=\frac{-100\left(\varepsilon+\varepsilon^{*}-1\right)}{\beta\left(\varepsilon^{*}-1\right)}$

which is positive since $\beta<0$. An "equal burden sharing" tariff will exist if the tariff rate that satisfies equation (19) exceeds the tariff rate that satisfies equation (8), and this will occur if:

$\left(\varepsilon+\varepsilon^{*}-1\right)>\left(\frac{-\beta}{50}\right)$ 
So, if $\beta$ is sufficiently large, (greater than $\left[50\left(\varepsilon+\varepsilon^{*}-1\right)\right]$ in absolute value) it will not be

possible to find a $\overline{\mathrm{t}}$. For this situation to occur, either the elasticity of supply of exports or the elasticity of substitution between goods in demand in the home country would need to be large.

\section{B. Distribution of the Cumulative Welfare Effects of a Tariff}

The previous sections dealt with the question of how the welfare effects that arise from a marginal change in the home country tariff are shared between the home country and the foreign (exporting) country. This section considers a slightly different question: How are the cumulative welfare effects of a tariff by the home country distributed?

Using equation (1), the level of welfare in the home country as a function of the tariff rate is:

$$
y=\int d y d t=\frac{p^{*} M \beta}{2\left(\varepsilon+\varepsilon^{*}-1\right)}\left[\left(\varepsilon^{*}-1\right) t^{2}-2 t\right]+F T
$$

where $y$ is real income in the home country and $F T$ is the free-trade level of welfare for the home country. Similarly for the foreign country, using equation (2):

$$
y^{*}=\int d y^{*} d t=\frac{p^{*} E^{*} \beta}{\left(\varepsilon+\varepsilon^{*}-1\right)} t+F T^{*}
$$

where $y^{*}$ is real income in the foreign country and $F T^{*}$ is the free-trade level of welfare for the foreign country.

\section{Relationship Between Welfare Levels at Home and Abroad}

Using (21) and (22), it is possible to find the tariff rates in the home country at which the levels of welfare in the home and foreign country are equal. The solutions for the home tariff rate are:

$$
t=\frac{\left[2+\left(\frac{2 p^{*} E^{*}}{p^{*} M}\right)\right] \pm \sqrt{\left[2+\left(\frac{2 p^{*} E^{*}}{p^{*} M}\right)\right]^{2}-4\left(\varepsilon^{*}-1\right)\left(\frac{-2\left(\varepsilon+\varepsilon^{*}-1\right)}{p^{*} M \beta}\right)\left[F T^{*}-F T\right]}}{2\left(\varepsilon^{*}-1\right)} .
$$


Under balanced trade, $p^{*} M=p^{*} E^{*}$, equation (23) reduces to:

$t=\frac{4 \pm \sqrt{16-4\left(\varepsilon^{*}-1\right)\left(\frac{-2\left(\varepsilon+\varepsilon^{*}-1\right)}{p^{*} M \beta}\right)\left[F T^{*}-F T\right]}}{2\left(\varepsilon^{*}-1\right)}$.

The solutions for $t$ fall into one of three cases:

\section{Case 1: $\boldsymbol{F T}=\boldsymbol{F T} \boldsymbol{T}^{*}$}

In this case, the free trade levels of real income in both countries are equal - that is, when $\mathrm{t}=0$, y equals $\mathrm{y}^{*}$. Setting FT equal to $\mathrm{FT}^{*}$ in (24) yields two solutions: $t_{1}=0$ and $t_{2}=\frac{4}{\varepsilon^{*}-1}$. If $\varepsilon^{*}$ is constant, then $t_{2}=4 t^{*}$.

The above result can be used to examine the case where the change in welfare in each country, relative to free trade, is equalized. By construction, $(y-F T)$ and $\left(y^{*}-F T^{*}\right)$ have the same intercept - the origin. Relative to free trade, the change in real income for the home country is:

$$
y-F T=\frac{p^{*} M \beta}{2\left(\varepsilon+\varepsilon^{*}-1\right)}\left[\left(\varepsilon^{*}-1\right) t^{2}-2 t\right]
$$

and similarly for the foreign county:

$$
y^{*}-F T^{*}=\frac{p^{*} E^{*} \beta}{\left(\varepsilon+\varepsilon^{*}-1\right)} t
$$

These welfare changes are equal for two values of the home country tariff, $t_{1}=0$, and

$$
t_{2}=\frac{2\left[1+\left(\frac{p^{*} E^{*}}{p^{*} M}\right)\right]}{\left(\varepsilon^{*}-1\right)} \text {, or } t_{2}=\frac{4}{\left(\varepsilon^{*}-1\right)} \text { when trade is balanced. }
$$

If $\varepsilon^{*}$ is constant for all levels of $\mathrm{t}$, then $t_{2}$ equals four times the optimal tariff for the home country. For tariffs greater than this level, the home country would be hurt more than the foreign country relative to free trade, while for home tariffs less than $t_{2}$, the foreign country would suffer a larger loss. This result is consistent with the results derived in Section II A. 
As is well known, the optimal tariff occurs where $t=\frac{1}{\left(\varepsilon^{*}-1\right)}$. Assuming $\varepsilon^{*}$ remains constant, the welfare effects of a marginal change in the home country tariff are equalized across the home and foreign country when $t=\frac{2}{\left(\varepsilon^{*}-1\right)}$, which of course, exceeds the optimal tariff.

Now, the cumulative welfare effect from a tariff in the home country, relative to free trade, is equalized when $t=\frac{4}{\left(\varepsilon^{*}-1\right)}$, which is still larger. The reason for this is that, although the welfare effects of a marginal tariff change were balanced at $2 t^{*}$, a larger tariff is needed to equate the cumulative welfare change relative to free trade, because the home country gained from a tariff up to $t^{*}$. Thus, a tariff larger than $2 t^{*}$ is required to balance the cumulative welfare changes.

\section{Case 2: $F T>F T^{*}$}

In this case, the free trade level of real income in the home country exceeds that in the foreign country. Therefore, the term under the square root in (24) will be positive. There will be two solutions for $t$, but one of them will be negative - an import subsidy.

\section{Case 3: $F T<F T^{*}$}

In this case, the term under the square root in (24) could be negative when:

$$
\left[4\left(\varepsilon^{*}-1\right)\left(\frac{-2\left(\varepsilon+\varepsilon^{*}-1\right)}{p^{*} M \beta}\right)\left(F T^{*}-F T\right)\right]>16
$$

If (28) holds, then there would be no tariff rates for the home country where $y$ equals $y^{*}$.

\section{Maximizing the Difference in Welfare Levels}

The difference between real income in the home and foreign country $\left(y-y^{*}\right)$ is:

$$
\left(y-y^{*}\right)=\frac{p^{*} M \beta}{2\left(\varepsilon+\varepsilon^{*}-1\right)}\left[\left(\varepsilon^{*}-1\right) t^{2}-2 t\right]-\frac{p^{*} E^{*} \beta}{\left(\varepsilon+\varepsilon^{*}-1\right)} t+\left(F T-F T^{*}\right)
$$

which reaches a maximum at $t=\frac{\left(\frac{p^{*} E^{*}}{p^{*} M}\right)+1}{\left(\varepsilon^{*}-1\right)}$, or $t=\frac{2}{\left(\varepsilon^{*}-1\right)}$ when trade is balanced, since $\frac{d\left(y-y^{*}\right)}{d t}=0$ and $\frac{d^{2}\left(y-y^{*}\right)}{d t^{2}}<0$ at this tariff rate in the home country. This result is consistent with the one derived in Section II A, namely, that the excess burden from a 
marginal change in the home country tariff is equalized at $t=\frac{2}{\left(\varepsilon^{*}-1\right)}$, where $\frac{d y}{d t}=\frac{d y^{*}}{d t}$.

Once this tariff rate is reached, the difference in real income levels in the two countries narrows as $t$ increases, since the welfare loss in the home country rises more rapidly than in the foreign country.

\section{Generalizations and Extensions}

The results derived above can be used to analyze the incidence of a variety of taxes, and not just tariffs, so long as the agent imposing the tax is able to influence the net-of-tax price of the taxed commodity. The results are valid for either a closed economy or for the case of two countries. In the case of $\mathrm{N}$ exporting countries, the likelihood a finding a tariff rate in the importing country that affects all countries equally is very remote. To find an "equal burden sharing" tariff across all exporters, each exporter would have to suffer the same terms-oftrade loss as the other. That is, $E^{*} d p^{*}$ would have to be the same across all exporting countries. With the terms-of-trade change common to all exporters, this implies that $E^{*}$ would have to be the same across all exporters, which is highly unlikely. Still, the results derived above are useful in the sense that a situation of $\mathrm{N}$ exporting countries could be treated in a manner similar to the two-country case by aggregating all the exporting countries and treating them as the rest of the world. Of course, the results would then only hold on average.

Note that the conclusions reached above do not necessarily apply to other types of trade interventions, such as export subsidies, although they do carry over to the case of export taxes. In a two-country world, a country that applies an export subsidy will be worse off because it suffers a terms-of-trade loss, as well as some distortionary cost. The importing country, however, enjoys a terms-of-trade gain, as it imports the subsidized good at a lower price. With many countries, the size of the welfare effects of an export subsidy in one country, relative to the welfare effects on competing exporters is less clear. For example, in the case of two competing exporters, an export subsidy by one country could hurt the other exporter by more than itself, if the size of the export sector in the non-subsidizing country is sufficiently large.

\section{Numerical ApPlications}

The new results noted above are significant because they suggest a simple method that could be used to assess how the welfare effects of a tariff are distributed. Assuming the elasticity of the foreign offer curve remains constant, a marginal tariff increase by the home country will hurt itself more than its trading partner if its actual tariff rate exceeds twice its optimal rate. This suggests an obvious two-step procedure for assessing the distribution of the welfare effects: (1) estimate the optimal tariff $\left(t^{*}\right)$ for the home country; and (2) compare the actual tariff rate to the rate at which the excess burdens from a marginal tariff change in the home country would be equalized. To assess the cumulative change in welfare, relative to free trade, compare the actual tariff rate to the tariff rate given by the expression (27). All that is required in step (1) is an estimate of the elasticity of the foreign offer curve (foreign elasticity of export supply in a partial equilibrium context). This method is simple, and with sensitivity 
testing, can provide information that is based on theory to evaluate the incidence of tariff protection. The remainder of this section provides an application of this method.

Even if the elasticity of the foreign offer curve is not constant, then the result in (9) is still useful in that it places an upper bound on the magnitude of the equal burden sharing tariff. Equation (9) established that it can not be larger than twice the optimal tariff. The reason for this is that as the home country raises its tariff, the home offer curve intersects the foreign offer curve on sections where $\varepsilon^{*}$ is increasing. As a result, the equal burden sharing tariff will be less than twice the optimal tariff. If $\varepsilon^{*}$ remained unchanged, the largest the equal burden sharing tariff could be would be twice the optimal tariff.

To assess tariff incidence using the results derived above, optimal tariff rates were calculated for three agricultural commodities: rice, sugar, and tobacco. Optimal tariffs in Quad countries (United States, Canada, the European Union, and Japan) for these commodities were calculated by using export-supply elasticities that were estimated by using data on production and exports from the Food and Agriculture Organization (FAO), along with estimates of domestic demand and supply elasticities available from Gardiner, Roningen, and Liu (1989). ${ }^{12}$ These export supply elasticities are assumed to remain constant along the export supply curve. The exporters chosen were Thailand (rice), and Brazil (sugar and tobacco). Actual tariff rates were taken from version 5 of the GTAP database, complied by Dimaranan and McDougall (2002). Using the data on the value of imports for each Quad country and the value of exports from Brazil and Thailand, tariff rates that equate the welfare effects of a marginal tariff change, as well as tariff rates where the level of real income, relative to free trade, are equalized are computed. The calculations are reported in Table 1.

For rice, actual tariff rates in the European Union and Canada are below the rates that would equalize the welfare effects at the margin, suggesting that a tariff increase in these countries would hurt Thailand more than themselves. Since Japan's protection on rice is far above the level at which the marginal burdens would be equalized, a reduction in Japan's rice protection would benefit Japan more than it would Thailand. Actual tariff rates on rice in the European Union and Canada are below the rates at which the cumulative welfare effects are equalized, relative to free trade, while the opposite is true for Japan. Therefore, relative to free trade, Japan is hurt more than Thailand, while Thailand is hurt more than the European Union and Canada.

For sugar, actual rates of protection in the United States, the European Union, and Japan, exceed the rate at which the welfare effects from a marginal tariff change would be balanced. Thus, these three countries would be hurt more than Brazil from a tariff increase. For the United States and Japan, their actual tariff rates are below the rates at which the cumulative

${ }^{12}$ Using the relationship $E=X-D$, where $E$ is exports, $X$ is production, and $D$ is domestic demand, $\varepsilon_{X}^{S}=\varepsilon_{S}\left(\frac{X}{E}\right)-\varepsilon_{D}\left(\frac{D}{E}\right)$, where $\varepsilon_{X}^{S}$ is the export-supply elasticity, $\varepsilon_{S}$ is the domestic supply elasticity, and $\varepsilon_{D}$ is the domestic demand elasticity. 
Table 1. Incidence of Quad Country Tariffs: Three Examples from Agriculture (Tariff rates in percent)

$\begin{gathered}\text { Optimal } \\ t^{*}=\frac{1}{\varepsilon_{S}}\end{gathered} \quad t=\frac{1+\left(\frac{p^{*} E^{*}}{p^{*} M}\right)}{\varepsilon_{S}} t=\frac{2\left[1+\left(\frac{p^{*} E}{p^{*} M}\right)\right]}{\varepsilon_{S}} \quad \begin{gathered}\text { Actual } \\ \text { Tariff } \\ \text { Rate }\end{gathered}$

Rice

$\begin{array}{lrrrr}\text { European Union } & 17.4 & 88.4 & 176.8 & 64.9 \\ \text { Japan } & 17.4 & 156.1 & 312.2 & 409.0 \\ \text { Canada } & 17.4 & 285.1 & 570.2 & 0.0\end{array}$

Sugar

United States

European Union

Japan

Canada

Tobacco

United States $\quad 550.8$

European Union $\quad 550.8$

Japan

Canada
550.8

9.3

9.3

9.3

9.3

550.8
47.1

33.3

67.9

97.2
94.2

66.6

135.8

194.4
53.4

76.4

116.1

4.9

Source: Gardiner et al. (1989); Food and Agriculture Organization, FAOSTAT; Dimaranan and McDougall (2002); and author's calculations.

welfare change, relative to free trade, would be equalized, while the EU's tariff is above this rate. Viewed in this manner, protection in the United States and Japan hurts Brazil more than themselves, relative to free trade, while the opposite is true with regard to the EU's tariff. For Canada, its protection hurts Brazil more than itself because its tariff is below the optimum. For tobacco, actual rates of protection in all four Quad countries are far below optimal tariffs, so Brazil is hurt more from tariffs in the Quad countries.

At an aggregate level, both Hamilton and Whalley (1985) and Markusen and Wigle (1989) conclude that actual tariff rates for the United States are far below calculated optimal tariff rates. If this is true, then a tariff increase by the United States would hurt its trading partner, while it would gain. Using Markusen and Wigle's estimate that the Nash equilibrium tariff 
for the United States is 18 percent, and assuming the elasticity of the foreign offer curve remains constant and trade is balanced, then at a tariff rate of 36 percent, the change in welfare from a tariff increase in the United States would be equalized against the rest of the world. Furthermore, it would take a 72 percent tariff in the United States to equalize the welfare effects, relative to free trade. Thus, at least for the United States, a tariff increase above current levels (about 3 percent on average) would hurt its trading partner more than itself. This conclusion holds on average, but of course, for particular products where protection is high in the Quad, the opposite could be true.

The above conclusions suggest that, currently, protection in Quad countries probably harms their trading partners more than themselves, given the low levels of protection in Quad countries on average. In light of this, perhaps a case could be made for "special and differential treatment" for developing countries in the WTO to compensate them for the greater losses that they suffer. For developing countries, there seems to be the perception that the burden of protection in these countries is borne by themselves, because they cannot influence their terms of trade. On the contrary, a large number of developing countries possess market power in a wide range of products, especially on the export side. Some of the products in which developing countries supply at least 10 percent of total world exports are aluminum, bananas, bauxite, cashew nuts, cinnamon, cocoa beans, coffee, copper, copra, cotton, iron ore, rubber, spices, sugar, tea, tin, vanilla, and zinc. ${ }^{13}$ In theory then, optimal export taxes exist for these and other products. Even if developing countries that have the ability to influence world prices do not have explicit export taxes in place, their tariff structure acts implicitly as a tax on their exports. The question then becomes where existing levels of protection in developing countries lie in relation to their optimal levels.

Most models of international trade routinely adopt the Armington assumption - treating imports and domestic goods within the same product classification as imperfect substitutes. One implication of this view is that every country has the incentive to apply an optimal export tax, since every country's export good differs from every other, even countries that may be thought to be "small" in the economic sense.

\section{Conclusions}

Recently, there has been a great deal of discussion about the distribution of the welfare effects of protection across countries, but unfortunately, the debate has not generally been based on sound theoretical principles. On the one hand, some have argued that industrial country trade policies hurt developing countries more than their own countries (such as in agriculture), while others have argued that developing countries mainly hurt themselves as a result of their own trade barriers. Of course, a small country bears the entire burden of its own protection, since it cannot influence its terms of trade. Thus the question becomes: what can be said about tariff incidence in the large country case?

${ }^{13}$ Shares of a country's exports in total world exports of a given product were calculated from the World Integrated Trade System (WITS) database. 
There are two ways of tackling the question of tariff incidence. One is to ask: What would be the distribution of the welfare effects across countries from a marginal change in the home country tariff? The second approach is to ask: What is the distribution of the cumulative welfare effects of a tariff change in the home country, perhaps relative to free trade, across countries? Regarding the first question, this paper shows that under certain assumptions, the welfare effects of a marginal change in the home country tariff are equalized across exporter and importer when the home tariff rate equals two divided by the elasticity of the foreign offer curve minus one. When the elasticity of the foreign offer curve is constant, the welfare effects are equal at twice the optimal tariff for the home country. Thus, the home country would be hurt more from a tariff increase if its actual tariff rate exceeded twice its optimal rate, while the foreign country would be hurt more if the home tariff were less than twice its optimal rate.

Regarding the cumulative welfare effects of a tariff in the home country relative to free trade, under appropriate assumptions, these are equalized across exporter and importer when the home country tariff equals four divided by the elasticity of the foreign offer curve minus one-four times its optimal tariff if the elasticity of the foreign offer curve is constant. Looking at the question of tariff incidence from this perspective, the home country would be hurt more than the foreign country, relative to free trade, if its actual tariff rate exceeded four times its optimal tariff; if the home tariff is less than four times its optimal tariff, the foreign country is hurt more than the home country. These results suggest a method that can be used in practice to assess tariff incidence.

More generally, the results in this paper hold for a variety of taxes, not just taxes on international trade, provided that the agent imposing the tax is able to affect the net-of-tax price of the taxed product. These results also hold in assessing tax incidence in a closed economy, as well as in a two-country model of international trade. 


\section{REFERENCES}

Anderson, Kym, Betina Dimaranan, Tom Hertel, Joe Francois, Bernard Hoekman, and Will Martin, 2001, "The Burden of Rich and Poor Country Protectionism on Developing Countries," Journal of African Economies, Vol. 10, No. 3 (September), pp. 227-57.

Bhagwati, Jagdish, 2002, “The Poor's Best Hope,” The Economist (June), pp. 24-26.

Caves, Richard, Jeffrey Frankel, and Ronald Jones, 2002, World Trade and Payments: An Introduction (Boston: Addison Wesley Longman).

Dimaranan, Betina V., and Robert A. McDougall, 2002, Global Trade, Assistance, and Production: The GTAP5 Data Base, Center for Global Trade Analysis, Purdue University.

Food and Agriculture Organization, 2000, FAOSTAT Database on Agriculture and Food Trade, available at http://www.fao.org.

Gardiner, Walter, Vernon Roningen, and Karen Liu, 1989, "Elasticities in the Trade Liberalization Database,” Economic Research Service (Washington).

Gorman, William, 1958, "Tariffs, Retaliation, and the Elasticity of Demand For Imports," Review of Economic Studies, Vol. 25, 3, pp. 133-162.

Hamilton, Bob, and John Whalley, 1983, "Optimal Tariff Calculations in Alternative Trade Models and Some Possible Implications For Current World Trading Arrangements," Journal of International Economics, Vol. 15 (November), pp. 323-348.

Johnson, Harry, 1953-54, "Optimum Tariffs and Retaliation,” Review of Economic Studies, Vol. 21, pp. 142-153.

Kennan, John, and Raymond Riezman, 1988, “Do Big Countries Win Tariff Wars?", International Economic Review, Vol. 29, No. 1, February.

Lerner, Abba, 1936, “The Symmetry Between Import and Export Taxes,” Economica, Vol. 3, pp. 306-13.

Markusen, James, 1981, "The Distribution of Gains From Bilateral Tariff Reductions," Journal of International Economics, Vol. 11, pp. 553-572.

Markusen, James, and Randall Wigle, 1989, "Nash Equilibrium Tariffs For the United States and Canada: The Roles of Country Size, Scale Economies, and Capital Mobility," Journal of Political Economy, Vol. 97, No. 2, pp. 368-86. 
Oxfam, 2002, "The Great EU Sugar Scam: How Europe's Sugar Regime is Devastating Livelihoods in the Developing World,” Oxfam Briefing Paper 27.

Panagariya, Arvind, 2002, "Alternative Approaches to Measuring the Cost of Protection," paper presented at the 2002 American Economic Association Meetings.

Stoeckel, Andrew, and Brent Borrell, 2001, "Preferential Trade and Developing Countries: Bad Aid, Bad Trade," Rural Industries Research and Development Corporation.

Tokarick, Stephen, 2003 "Measuring the Impact of Distortions in Agricultural Trade in Partial and General Equilibrium," IMF Working Paper No. 03/110 (Washington: International Monetary Fund). 